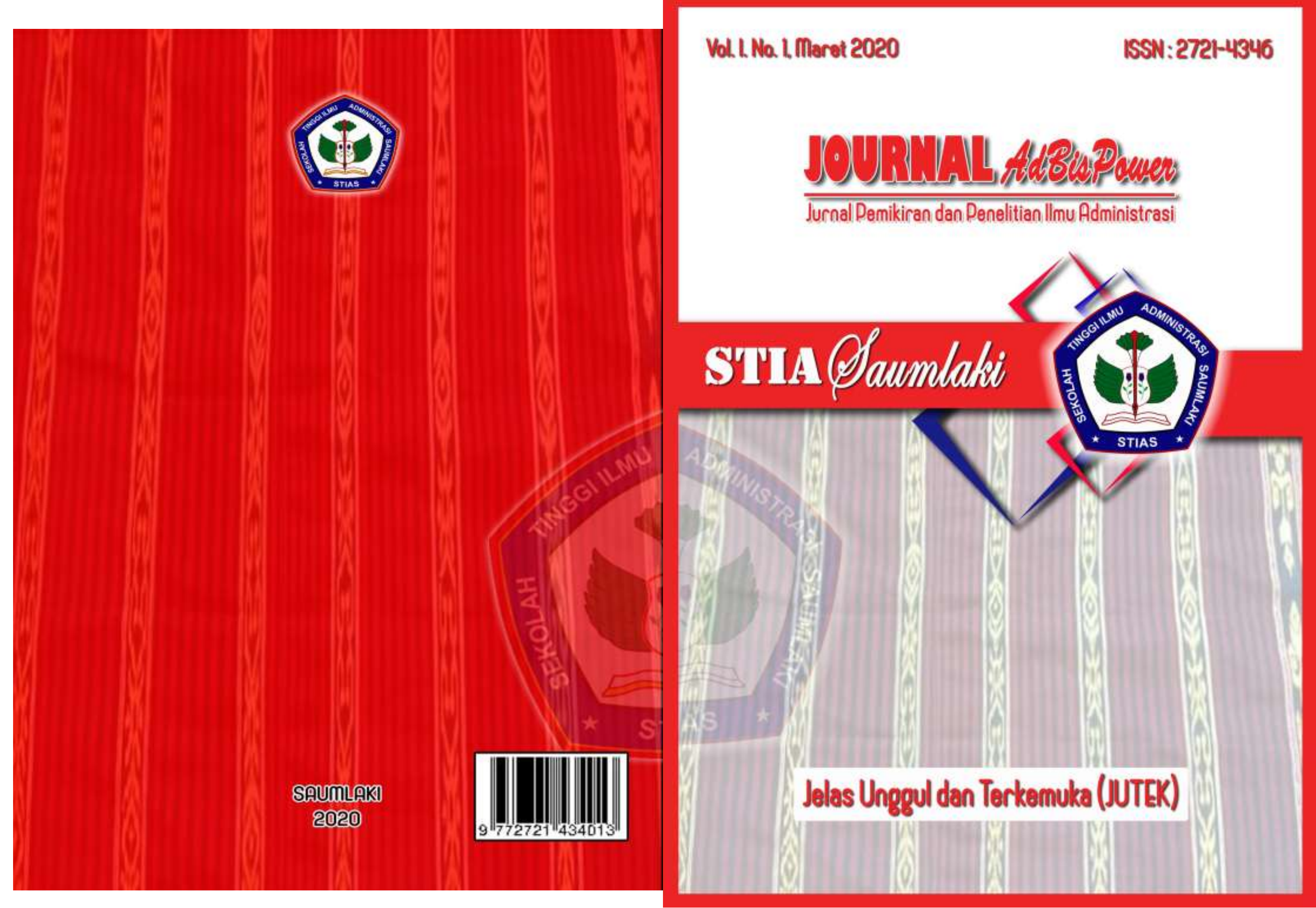




\title{
BIROKRASI KABUPATEN KEPULAUAN TANIMBAR SEBAGAI GELANGGANG PATRONASE
}

Oleh :

Pieter Frits Emanratu

(Dosen STIA Saumlaki)

\begin{abstract}
ABSTRAK
Penelitian ini bertujuan untuk mengetahui dan menganalisis posisi birokrasi secara politik, serta kecenderungan dijadikannya birokrasi sebagai arena distribusi kepentingan atau gelanggang patronase pada birokrasi di Kabupaten Kepulauan Tanimbar. Metode yang digunakan dalam penelitian ini ialah pendekatan kualitatif dengan teknik analisis data menggunakan model menggunakan Model Miles Dan Huberman, melalui prosedur Reduksi Data, Penyajian Data, dan Penarikan Kesimpulan.

Berdasarkan hasil penelitian yang dilakukan, ditemukan adanya keterlibatan sejumlah pegawai ASN di lingkungan Pemerintah Kabupaten Kepulauan Tanimbar dalam kegiatan politik praktis. Keikutsertaan para ASN dalam kegiatan politik praktis sekaligus memastikan kebenaran tentang hubungan patron klien antara birokrat dan politisi yang kemudian berlanjut pada pemanfaatan birokrasi sebagai arena distribusi kepentingan.
\end{abstract}

Kata Kunci : Birokrasi, Patronase

\section{ABSTRACT}

This study aims to identify and analyze the political position of the bureaucracy, as well as the tendency to make the bureaucracy as an arena for distributing interest or a patronage arena for the bureaucracy in the Tanimbar archipelago district. The method used in this research is a qualitative approach with data analysis techniques using the Miles and Huberman model, through data reduction procedures, data presentation, and drawing conclusion.

Based on the result of the research conducted, it was found that a number of ASN employees un the Tanimbar Island District Government were involved in practical political activities. The participation of civil servants in practical political activities while ensuring the truth about the patron-client relationship between bureaucrats and politicians which then continues to use rhe bureaucracy as an arena for distributing interests

Keywords : Bureaucracy, Patronage 


\section{PENDAHULUAN}

Masalah Birokrasi bukan hanya pada hierarki dan sistem kewenangannya yang kaku, tetapi juga berkaitan dengan oligarki sebagai akibat dari pertarungan elite politik. Praktek - praktek klasik warisan Orde Baru dengan gamblang dipertontonkan pada setiap awal ataupun akhir dari suatu kontestasi politik. Kelompok pemenang selalu berusaha menunjukan eksistensinya dalam menguasai suatu sistem pemerintahan pada setiap tingkatan atau jenjang kekuasaan.

Pada saat yang bersamaaan di luar struktur dan institusi pemerintahan telah muncul hasrat yang makin kuat untuk membudayakan demokratisasi dengan memberdayakan masyarakat sipil (civil Society). Keinginan ini terefleksi dengan adanya tuntutan untuk mengubah secara substansial dan fundamental pola hubungan politik yang semakin bercorak egaliter (Alaslan, 2021: 2)

Keadaan inilah yang memicuh terjadinya fenomenah "cuci gudang" atau "bersih - bersih" pada Birokrasi Pemerintahan yang bukan bagian dari kelompok pemenangan. Cuci gudang ataupun bersih - bersih bisa juga istilah lain yang berkembang pada suatu daerah tertentu namun masih dalam pengertian yang sama, seringkali memposisihkan birokrasi sebagai arena aduh kekuatan politik.

Politik yang menguasai kekuasaan dan birokrasi yang menjalankan pemerintahan menjadi sebab munculnya hubungan yang tidak seimbang tetapi saling membutuhkan. Birokrasi sebagai jembatan penghubung antara kebutuhan masyarakat dengan keinginan penguasah memperkuat posisi tawarnya, sementara politik yang menguasai sumber - sumber kekuasaan selalu mampu mengendalikan para birokrat serta mempengaruhi sistem birokrasi dengan dalih jenjang karier. Birokrasi bukan hanya berisikan birokrat karier tetapi juga antek kekuasaan dengan tujuan membangun oligarki. Promosi dan penempatan jabatan tidak didasarkan pada profesionalisme dan kompetensi sebagaimana idealnya prinsip merit sistem, tetapi lebih mengutamahkan kedekatan emosional atau kekerabatan sehingga kecenderungan untuk menjadikan Birokrasi sebagai gelanggang patronase seringkali tidak terelakan.

\section{LANDASAN TEORI}

\section{Birokrasi}

Secara Etimologis :Kata birokrasi berasal dari :"bureau" (bahasa Perancis): kantor dan "kratia" atau "kratos" (bahasa Yunani) $=$ kekuasaan atau aturan.Dari asal kedua kata "bureau" dan "kratos" dapat diartikan birokrasi adalah bentuk 
kekuasaan atau pengaturan urusan publik di tangan kantor-kantor (pemerintah).

Dalam Kamus Besar Bahasa Indonesia, birokrasi didefinisikan sebagai : Sistem pemerintahan yang dijalankan oleh pegawai pemerintah karena telah berpegang pada hirarki dan jenjang jabatan. Cara bekerja atau susunan pekerjaan yang serba lamban, serta menurut tata aturan (adat dan sebagainya) yang banyak liku-likunya dan sebagainya.

Konsep dan defenisi tentang birokrasi juga dikemukakan oleh para ahli,diantaranya Max Weber dalam Mifta Thoha (2016 : 15) yang berpendapat bahwa Birokrasi adalah suatu organisasi yang berlandaskan sistem kewenangan yang sah dan formal (legitimate and formal). SementaraHegel dalam Mifta Thoha (2016: 22)berpendapat bahwa birokrasi adalah medium yang dapat dipergunakan untuk menghubungkan kepentingan partikular dengan kepentingan general (umum). Pendapat Hegel dikritisi oleh Karl Marx dalam Mifta Thoha (2016:23), yang berpendapat bahwa birokrasi merupakan instrumen yang dipergunakan oleh kelas yang dominan untuk melaksanakan kekuasaan dominasinya atas kelas-kelas sosial lainnya, dengan kata lain birokrasi memihak kepada kelas partikular yang mendominasi tersebut.
Pendapat ketiga ahli ini membawa pemahaman peneliti dalam melihat birokrasi sebagai bentuk bangunan berisihkan kalangan elit, yang memainkan peranan mereka oleh karena kewenangan yang melekat pada mereka.Birokrasi dalam defenisinya juga dipahami sebagai sesuatu yang dibutuhkan dalam upayah untuk mengatasi persoalan yang kompleks, sebagaimana yang dikemukakan oleh Bintoro Tjokroamidjojo (1984) "Birokrasi dimaksudkan untuk mengorganisir secara teratur suatu pekerjaan yang harus dilakukan oleh banyak orang”.Pendapat ini diperkuat oleh Blau dan Page (1956) yang mengemukakan "Birokrasi sebagai tipe dari suatu organisasi yang dimaksudkan untuk mencapai tugas-tugas administratif yang besar dengan cara mengkoordinir secara sistematis (teratur) pekerjaan dari banyak orang”.

\section{Birokrasi Dan Politik}

Setiyono dalam bukunya "Birokrasi dalam perspektif politik dan administrasi” (2016:66-74), menjelaskan bahwa Setidaknya ada tiga alasan untuk menilai mengapa birokrasi sangat kuat secara politik, yakni :

1. Kepemilikan asset sumber kekuasaan

2. Peranan birokrasi yang istimewa di tengah masyarakat, serta 
3. Posisi birokrasi yang strategis dalam hubungan penguasa dan rakyat.

Dengan realitas seperti ini, setiap penguasa selalu berhadapan dengan dua masalah ketika berhadapan dengan birokrasi. Pertama, bagaimana mengkomunikasikan gagasan/visi kekuasaan, artinya penguasa harus bisa mencapai kesepakatan-kesepakatan dengan birokrasi untuk melaksanakan logframe (kerangkah logis) kekuasaan. Kedua, memastikan bahwa gagasan itu dilaksanakan oleh mereka, yakni penguasah harus bisa mengontrol birokrasi agar tidak bekerja sekehendak hati mereka saja.

\section{Patronase Politik : Birokrasi Sebagai Arena Distribusi Kepentingan.}

Patronase merupakan konsep kekuasaan yang lahir dari hubungan yang tidak seimbang antara patron di satu pihak dank lien di pihak yang lain. Ketidakseimbangan ini pada dasarnya berkait erat dengan kepemilikan yang tidak sama atas sumber daya dalam asyarakat. Karena itu, dalam fenomenah seperti ini, interelasi telah diikat oleh kepentingan dan dimanipulasi oleh tujuan masing-masing walaupun keduanya berada dalam kedudukan yang tidak seimbang.

Dalam konteks ini dipahami bahwa patronase adalah hubungan yang tidak setara tetapi saling membutuhkan. Di satu pihak, patron muncul sebagai individu yang mempunyai kelebihan baik dilihat dari aspek kekayaan, status dan pengaruh; sedangkan di lain pihak, klien hadir sebagai anggota masyarakat yang tidak memiliki sumber-sumber daya tersebut.

Pemimpin atau sang Patron merupakan motor atau daya penggerak semua sumber-sumber dan alat-alat (resources) yang tersedia dalam suatu organisasi. Oleh karena itu, dalam konteks ini dapat dimaknai sebagai hubungan yang berlandaskan pertukaran kepentingan (Alaslan, 2021: 95)

Asumsi dasar kerangka konsep ini meletakan cara berpikir yang menandaskan bahwa hubungan akan terjadi apabilah kedua belah pihak dapat memperoleh keuntungan-keuntungan dari hubungan yang mereka jalin. Paling tidak mekanisme itu seperti dijelaskan bahwa kelompok patron memberikan bantuan ekonomi dan perlindungan kepada golongan klien atau bawahannya, dan sebagai balasan atas pemberian tersebut, maka golongan klien memberikan pengabdian dan kesetiaannya kepada sang patron.

Kendati hubungan patronase berlandaskan pada nilai pertukaran kepentingan, tetapi pertukaran tersebut tetaplah tidak seimbang. Ini dikarenakan oleh penguasaan secara langsung terhadap 
sumber-sumber daya utama first order resources) yang terdapat dalam skop masyarakat ataupun negara. Sumbersumber ini bisa berupa jabatan, pekerjaan, lisensi, dan lain-lain. Sejalan dengan fenomenah ini, maka wujud pola patron lapis kedua yang tidak memiliki sumbersumber daya utama atau strategis, tetapi memiliki akses terhadapnya (second order resources) yang disebut sebagai broker. Pada broker yang menjadi perantara antara patron utama dengan klien tumbuh subur di negara otoktratik, Karena dianggap sebagai kepanjangan tangan dari individu-individu yang memiliki first order resources.

Sejalan dengan perbincangan di atas, transformasi politik yang tengah berlaku di Indonesia, dimana kepala daerah dipilih langsung oleh rakyat, telah memberikan dampak negatifnya tersendiri bagi proses demokratisasi. Ini karena pemilihan kepala daerah langsung telah membuka ruang bagi patronase yang lebih dalam lagi.Sebab para kepala daerah terpilih berusaha menggunakan kedudukannya untuk memainkan peranan sebagai pemilik sumber utama. Peranan ini bukanlah satu hal yang sukar untuk dilaksanakan oleh para kepala daerah, melalui kedudukannya, para pemimpin politik ini mempunyai banyak peluang untuk menggunakan institusi publik sebagai domain kekuasaannya, serta mendistribusikan public resource yang berada di bawah kendalinya sebagai alat pertukaran bagi tujuan tertentu pada suatu hari nanti. Manakala para tim sukse pula telah berubah menjadi broker politik karena dianggap memiliki second order resources.

Keadaan seperti terurai di atas secara otomatis semakin memperkuat kedudukan dan peranan kepala daerah sebagai patron di kawasan yang berada di bawah kekuasaannya. Logika ini secara sederhana menjelaskan betapa pemimpin eksekutif di level lokal mempunyai kesempatan untuk mengawal dan mendistribusikan berbagai sumber publik (jabatan, anggaran, lisensi, proyek, dan lainnya) untuk mempertahankan serta meningkatkan kedudukan dan peranannya sebagai penguasa. Realitas di atas, senada dengan argumen Weingrod (1968:384) dalam Agustino (2014:175) menyatakan "close association of party with government opens new possibilities for patronage; once gained control of these resources the parties use them to serve their own electoral ends." Dalam arti kata lain, bertambahnya peranan kepala daerah melalui partai politik yang menyokongnya dalam merancang dan menyesiakan fasilitas sosio-ekonomi membuat para pemimpin politik ini mempunyai peluang untuk menawarkan berbagai kemudahan kepada anggota masyarakat yang menjadi 
sasaran pelaksanaan program pembangunan tersebut. Oleh karenanya, institusi birokrasi di tingkat daerah dengan mudah dijadikan gelanggang bagi tawar menawar kepentingan elit lokal.

Allison dalam kajiannya yang berjudul Bureaucratic politics (1978) yang dikutip dalam Agustino (2014:175), menyatakan bahwa aparatur birokrasi yang menduduki posisi tinggi dengan kewenangan yang tinggi pula bisa bertindak sebagai seorang pemain utama dalam arena yang disebutnya sebagai bureaucratic politics. Ini karena para aparatur birokrasi berposisi tinggi tersebut terlibat secara aktif dalam setiap kontestasi dalam birokrasi, dan secara serius membangun kroninya sendiri untuk mempertahankan kepentingannya.Tidak hanya itu, lebih lanjut menurutnya, berbagai kebijakan yang dihasilkan oleh para birokrat ini merupakan political bargaining outcomes.Dalam konteks ini, outcome harus dipahami bukan saja sebagai solusi atas pergulatan kepentingan, tetapi juga sebagai hasil kompromi atau bahkan koalisi. Pertanyaannya sekarang, apa kepentingan para aktor atau elit birokrat ketika mereka bermain dalam arena birokrasi, setidaknya ada empat jawaban yang dijelaskan oleh Geddes (1994) dalam Agustino (2014:175-176). Pertama, birokrasi bisa dijadikan sebagai sumber keuntungan yang dapat dibagikan kepada konstituen penyokongnya.Kedua, birokrasi dijadikan sebagai lahan patronase.Ketiga, birokrasi dijadikan sumber untuk menjaring anggota-anggota baru dari organisasi politik yang ada.Dan keempat, birokrasi dijadikan sebagai sarana pelaksanaan kebijakan yang menguntungkan kelompok-kelompok kepentingan yang ada dalam masyarakat yang berafiliasi dengan para elit birokrat ataupun politisi.Argumen Geddes ini paling tidak selaras juga dengan kajian sebelumnya yang dibuat oleh Ripley (1978) dalam Agustino (2014:176), yang menyatakan bahwa paling tidak ada dua kepentingan utama yang mendorong politisi menggunakan birokrasi sebagai arena politiknya.Pertama, dalam rangka memaksimalkan kemungkinankemungkinan untuk kepentingan pemilihan umum yang berikutnya, dan kedua, memberikan layanan pada konstituennya.

Merujuk pada penjelasan di atas, maka Leo Agustino berpendapat bahwa elit politik dan birokrat sama-sama memanfaatkan birokrasi untuk beberapa tujuan. Pertama, bagi kepala daerah; dijadikan tempat untuk mendistribusikan proyek dan formasi kepegawaian kepada kroninya seperti tim sukses, elit birokrat yang mendukungnya karena mengarahkan anggota dinas, badan dan lembaga yang 
dipimpinnya untuk mendukung calon dan elit ekonomi (investor politik). Kedua, bagi tim sukses dan birokrat; dijadikan wahana untuk memperoleh, mempertahankan, dan bahkan memperluas kekuasaannya dalam birokrasi.

\section{METODOLOGI PENELITIAN}

Penelitian ini menggunakan pendekatan kualitatif dengan teknik pengumpulan data lebih banyak pada observasi participant (participant opservation), wawancara mendalam dan dokumentasi, untuk selanjutnya dianalisis dengan menggunakan Model Miles Dan Huberman, melalui prosedur Reduksi Data, Penyajian Data, dan Penarikan Kesimpulan

\section{PEMBAHASAN}

Max Weber dalam Mifta Thoha (2016 : 15) yang berpendapat bahwa Birokrasi adalah suatu organisasi yang berlandaskan sistem kewenangan yang sah dan formal (legitimate and formal). Sementara Hegel dalam Mifta Thoha (2016: 22)berpendapat bahwa birokrasi adalah medium yang dapat dipergunakan untuk menghubungkan kepentingan partikular dengan kepentingan general (umum). Pendapat Hegel dikritisi oleh Karl Marx dalam Mifta Thoha (2016:23), yang berpendapat bahwa birokrasi merupakan instrumen yang dipergunakan oleh kelas yang dominan untuk melaksanakan kekuasaan dominasinya atas kelas-kelas sosial lainnya, dengan kata lain birokrasi memihak kepada kelas partikular yang mendominasi tersebut.

Birokrasi cenderung dijadikan sebagai arena distribusi kepentingan dalam konsep patronase politik yang adalahkonsep kekuasaan yang lahir dari hubungan yang tidak seimbang antara patron di satu pihak dank lien di pihak yang lain. Dalam konteks ini dipahami bahwa patronase adalah hubungan yang tidak setara tetapi saling membutuhkan.Oleh karena itu, dapat dimaknai sebagai hubungan yang berlandaskan pertukaran kepentingan. Asumsi dasar kerangka konsep ini meletakan cara berpikir yang menandaskan bahwa hubungan akan terjadi apabilah kedua belah pihak dapat memperoleh keuntungan-keuntungan dari hubungan yang mereka jalin.

Merujuk pada penjelasan di atas, maka Leo Agustino berpendapat bahwa elit politik dan birokrat sama-sama memanfaatkan birokrasi untuk beberapa tujuan. Pertama, bagi kepala daerah; dijadikan tempat untuk mendistribusikan proyek dan formasi kepegawaian kepada kroninya seperti tim sukses, elit birokrat yang mendukungnya karena mengarahkan anggota dinas, badan dan lembaga yang 
dipimpinnya untuk mendukung calon dan elit ekonomi (investor politik). Kedua, bagi tim sukses dan birokrat; dijadikan wahana untuk memperoleh, mempertahankan, dan bahkan memperluas kekuasaannya dalam birokrasi.

Berdasarkan hasil penelitian yang dilakukan, ditemukan adanya keterlibatan sejumlah pegawai ASN di lingkungan Pemerintah Kabupaten Kepulauan Tanimbar dalam kegiatan politik praktis yang secara otomatis, pegawai-pegawai tersebut tidak dapat membuktikan netralitas mereka pada saat momentum politik. Keikutsertaan para ASN dalam kegiatan politik praktis sekaligus memastikan kebenaran tentang hubungan patron klien antara birokrat dan politisi yang kemudian berlanjut pada pemanfaatan birokrasi sebagai arena distribusi kepentingan. Praktek cuci gudang atau bersih - bersih sebagaimana kegelisahan peneliti ternyata berlaku juga pada pemerintahan Kabupaten Kepulauan Tanimbar, dibuktikan dengan terjadinya promosi jabatan pada beberapa birokrat tetapi juga adanya mutasi bahkan pemecatan secara tidak dengan hormat dengan Dalih Ketentuan Peraturan Perundang - undangan.

\section{KESIMPULAN}

1. Birokrasi memiliki posisi kuat secara politik karena merupakan penghubung antara kebutuhan masyarakat dan keinginan penguasah.

2. Birokrasi seringkali dijadikan sebagai arena distribusi kepentingan oleh karena polah hubungan yang tidak seimbang antara birokrat dan politisi

3. Patronase pada birokrasi akan terus terjadi selama sistem pemerintahan di setiap tingkatan masih dipimpin oleh pejabat politik yang lahir dari suatu proses politik

\section{DAFTAR PUSTAKA}

Agustino Leo, 2014, Politik lokal dan Otonomi Daerah, Alfabeta. Bandung

Alaslan, Amtai. 2021. Formulasi Kebijakan Publik: Studi Relokasi Pasar. Banyumas: CV. Pena Persada

Alaslan, Amtai. 2021. Gaya Kepemimpinan dan Pembangunan Desa. Journal AdBisPower STIA Saumlaki Vol. 1. No. 1

Setiyono Budi. 2015, Birokrasi dalam perspektif politik dan administrasi.Nuansa. Bandung

Sugiyono.2015, Memahami penelitian kualitatif.Alfabeta. Bandung. 
Syafie Inu Kencana.2006, Ilmu administrasi public (edisi revisi).Rineka cipta. Jakarta.

Thoha Mifta 2014, Birokrasi dan dinamika kekuasaan.Prenadamedia group. Jakarta.

ThohaMifta. 2014, Birokrasi politik dan Pemilihan Umum di Indonesia.Prenadamedia group. Jakarta.

ThohaMifta. 2016, Birokrasi dan Politik di Indonesia. Rajawali Pers. Jakarta. 